\title{
Sire evaluation based on first lactation milk yield traits in HF X Gir halfbred
}

\author{
UY Bhoite ${ }^{1}$, MG Mote ${ }^{2}$ and PB Adsul ${ }^{3}$
}

Received: 21 April 2020 / Accepted: 11 July 2020 / Published online: 27 October 2020

(c) Indian Dairy Association (India) 2020

\begin{abstract}
The data on first lactation milk production performance of 422, HF X Gir halfbred cows maintained at Research Cum Development Project on Cattle, MPKV, Rahuri were utilized for estimation of least squares means, correlation among the traits and heritability of traits. Breeding values of sires were estimated by REML computer programme. The overall least squares means $(\mathrm{kg})$ of first lactation monthly test day milk yield (from $1^{\text {st }}$ to $6^{\text {th }}$ month) (FLMTDMY), first lactation peak milk yield (FLPMY) and first lactation 300 days milk yield (FL300 DMY) were $10.54 \pm 0.14,10.57 \pm 0.13,10.10 \pm 0.12,9.48 \pm 0.12,8.93 \pm$ $0.11,8.23 \pm 0.11,14.22 \pm 0.14$ and $2438.98 \pm 38.49$ respectively. Phenotypic and genotypic correlations among the traits were positive and significant $(\mathrm{P}<0.01)$. Heritability of traits was low to moderate and ranged from 0.06 to 0.25 . Sire number HG-412 and HG-129 had highest breeding values for FLMTDMY and H-28I and HG-15 had highest breeding value for FLPMY and FL300DMY and ranked first.
\end{abstract}

Keywords: FLMTDMY, FLPMY, FL300 DMY , HF X Gir halfbreds, Sire evaluation

To bring about improvement in milk production of cattle, it is must to execute breed improvement program for genetic evaluation

\footnotetext{
${ }^{1}$ Department of AHDS, PGI, MPKV, Rahuri, Dist. Ahmednagar.

Maharashtra, India

${ }^{2}$ RCDP on Cattle, MPKV, Rahuri, Dist. Ahmednagar, Maharashtra, India

${ }^{3}$ Department of AHDS, PGI, MPKV, Rahuri, Dist. Ahmednagar.

Maharashtra, India

Mahendra Gorakh Mote $(\triangle)$

Department of Animal Husbandry and Dairy Science

Mahatma Phule Krishi Vidyapeeth, Rahuri 413 722, Maharashtra, India

Email: mahendramote18@gmail.com
}

of males and females through selection of superior animals of high genetic merit. Based on first lactation milk production, the animal can be selected for future breeding. Use of monthly part lactation yields will be useful in selecting cows during early younger age resulting in reduced generation interval, increased intensity of selection attributed to the availability of more number of records on daughters having monthly records. The usefulness of part lactation records depends upon the accuracy with which sires are evaluated on the basis of these records besides the genetic correlations between part lactation milk yield records and 305- day milk yield. Literature available on part lactation milk yield also revealed that these milk yields can be used for prediction of 305-day milk yield as high genetic association between monthly part lactation milk yield and complete milk production records was observed Mundhe et al. (2018). Sire evaluation is most essential for selection of sire and for genetic improvement of cattle. It is also needful as majority of genetic improvement can be made through selection of males rather than females. Success of breeding programme depends on how early and accurately young bulls are evaluated. Systematic evaluation of bulls need complete records of daughters at least for first lactation. Hence, the present investigation was undertaken with the objective of estimation of breeding value of sires using first lactation monthly milk yield, peak milk yield and 300 days milk yield of the daughters.

The data for research were collected from pedigree, history and milk recording sheets of $422 \mathrm{HF} \mathrm{X} \mathrm{Gir} \mathrm{cows} \mathrm{maintained} \mathrm{for} \mathrm{period}$ of 43 years from 1974 to 2016 at Research Cum Development Project on Cattle, Mahatma Phule Krishi Vidyapeeth, Rahuri.

The data of first lactation $1^{\text {st }}$ to $6^{\text {th }}$ monthly test day milk yield (FLMTDMY), first lactation peak milk yield (FLPMY) and first lactation 300 days milk yield (FL300DMY) were estimated by least squares technique (Harvey, 1990) by considering period of calving and season of calving effects. Period of calving were grouped as $\mathrm{P}_{1}$ (1974-80), $\mathrm{P}_{2}$ (1981-87), $\mathrm{P}_{3}$ (1988-94), $\mathrm{P}_{4}$ (1995-2001), $\mathrm{P}_{5}$ (2002-08) and $\mathrm{P}_{6}(2009-16)$. Season of calving were divided as $\mathrm{S}_{1}$ (Rainy), $\mathrm{S}_{2}$ (Winter) and $\mathrm{S}_{3}$ (Summer). Duncan's Multiple Range Test (DMRT) as modified by Kramer (1957) was used to make pairwise comparison among least squares means. Data were corrected for significant effects of non-genetic factors and used 
for estimation of genetic parameters as suggested by Gacula et al. (1968) and sire evaluation. Heritability of traits was estimated by Paternal half sib correlation method, genetic correlations were computed by Paternal half sib analysis of co-variance method and phenotypic correlations among traits were estimated according to procedure suggested by Snedecor and Cochran (2004). The HF X Gir half bred sires were evaluated on the basis of their breeding values estimated by Restricted Maximum Likelihood (REML) computer programme using univariate model (Meyer, 1998).

The least squares analysis of various means of first lactation monthly test day milk yield, peak milk yield and 300 days milk yield of HF X Gir half bred are presented in Table 1,2 and 3. The overall mean first lactation test day milk yield from $1^{\text {st }}$ to $6^{\text {th }}$ month was $10.54 \pm 6.14 \mathrm{~kg}$. The analysis of variance indicated that the effect of period of calving on monthly test day milk yield was significant $(\mathrm{P}<0.01)$. Similar results were reported by Rashia Banu (2010) in Karan Fries cattle. The results showed that first lactation monthly test day milk yield from $1^{\text {st }}$ to $6^{\text {th }}$ month of cows calved during $\mathrm{P}_{1}$ (1974 to 1980) was significantly higher than those calved in rest of the periods. The influence of season of calving on monthly test day milk yield of HF X Gir cows was nonsignificant. The monthly test day milk yield was highest in cows calved during winter season in all months except first month. This might be due to favorable climate and adlib fodder available during winter season.

The overall mean first lactation peak milk yield in HF X Gir halfbred was $14.22 \pm 0.14 \mathrm{Kg}$. The effect of POC on FLPMY was significant $(\mathrm{P}<0.01)$. The peak milk yield of cows calved during $P_{1}$ (1974 to 1980$)$ was significantly higher $(16.95 \pm 0.24 \mathrm{~kg})$ than those calved during rest of periods. Peak milk of cows calved during $\mathrm{P}_{2}$ (1981 to 1987), $\mathrm{P}_{5}$ (2002 to 2008) and $\mathrm{P}_{6}$ (2009 to 2016) did not differed significantly from each other and significantly higher than calved in $\mathrm{P}_{3}$ (1988 to 1994) and $\mathrm{P}_{4}$ (1995 to 2001) periods. The variation due to season of calving in peak milk yield of Gir halfbred was non-significant. The FLPMY was

Table 1 Least squares means of monthly test day milk yield (kg)

\begin{tabular}{|c|c|c|c|c|c|c|c|}
\hline $\begin{array}{l}\text { Source of variation } \\
\text { Population mean }(\mu)\end{array}$ & $\mathrm{N}$ & $\mathrm{T}_{1}$ & $\mathrm{~T}_{2}$ & $\mathrm{~T}_{3}$ & $\mathrm{~T}_{4}$ & $\mathrm{~T}_{5}$ & $\mathrm{~T}_{6}$ \\
\hline \multicolumn{8}{|l|}{ Period of calving } \\
\hline $\mathrm{P}_{2}(1981-1987)$ & 665 & $11.10 \pm 0.32^{\mathrm{b}}$ & $10.79 \pm 0.31^{\mathrm{b}}$ & $9.95 \pm 0.29^{b}$ & $9.21 \pm 0.28^{b}$ & $8.76 \pm 0.27^{b}$ & $8.30 \pm 0.26^{\mathrm{b}}$ \\
\hline $\mathrm{P}_{3}(1988-1994)$ & 666 & $9.51 \pm 0.32^{\mathrm{d}}$ & $9.39 \pm 0.31^{\mathrm{e}}$ & $9.31 \pm 0.29^{b}$ & $8.71 \pm 0.28^{b}$ & $8.15 \pm 0.27^{b}$ & $7.66 \pm 0.26^{\mathrm{bc}}$ \\
\hline $\mathrm{P}_{6}(2009-2016)$ & 31 & $10.66 \pm 0.47^{b}$ & $10.23 \pm 0.45^{b}$ & $9.88 \pm 0.43^{b}$ & $9.09 \pm 0.41^{\mathrm{b}}$ & $8.45 \pm 0.39^{\mathrm{b}}$ & $7.71 \pm 0.38^{\mathrm{bc}}$ \\
\hline \multicolumn{8}{|l|}{ Season of calving } \\
\hline $\mathrm{S}_{1}$ (Rainy) & 1109 & $10.40 \pm 0.26$ & $10.32 \pm 0.24$ & $9.83 \pm 0.23$ & $9.31 \pm 0.23$ & $8.90 \pm 0.21$ & $8.30 \pm 0.21$ \\
\hline $\mathrm{S}_{2}$ (Winter) & 1153 & $10.57 \pm 0.21$ & $10.78 \pm 0.20$ & $10.35 \pm 0.19$ & $9.76 \pm 0.19$ & $9.16 \pm 0.18$ & $8.43 \pm 0.17$ \\
\hline $\mathrm{S}_{3}$ (Summer) & 1160 & $10.66 \pm 0.21$ & $10.62 \pm 0.20$ & $10.13 \pm 0.19$ & $9.37 \pm 0.19$ & $8.71 \pm 0.18$ & $7.97 \pm 0.17$ \\
\hline
\end{tabular}

Means under each class in the same column with different superscript differed significantly

Table 2 Effect wise least squares means of first lactation peak milk yield

\begin{tabular}{|c|c|c|}
\hline Source of variation & $\mathrm{N}$ & $\operatorname{Mean}(\mathrm{kg}) \pm \mathrm{SE}$ \\
\hline Population mean $(\mu)$ & 421 & $14.22 \pm 0.14$ \\
\hline \multicolumn{3}{|l|}{ Period of calving } \\
\hline$P_{2}(1981-1987)$ & 65 & $13.93 \pm 0.34^{\mathrm{b}}$ \\
\hline $\mathrm{P}_{3}(1988-1994)$ & 66 & $12.71 \pm 0.34^{\mathrm{d}}$ \\
\hline $\mathrm{P}_{4}(1995-2001)$ & 73 & $13.29 \pm 0.32^{\mathrm{c}}$ \\
\hline $\mathrm{P}_{6}(2009-2016)$ & 31 & $14.62 \pm 0.49^{b}$ \\
\hline \multicolumn{3}{|l|}{ Season of calving } \\
\hline$S_{1}$ (Rainy) & 109 & $14.08 \pm 0.27$ \\
\hline $\mathrm{S}_{2}$ (Winter) & 153 & $14.36 \pm 0.22$ \\
\hline $\mathrm{S}_{3}$ (Summer) & 160 & $14.23 \pm 0.22$ \\
\hline
\end{tabular}

Means under each class in the same column with different superscript differed significantly 
Table 3 Effect wise least squares means of FL300DMY

\begin{tabular}{|c|c|c|}
\hline Source of variation & $\overline{\mathrm{N}}$ & Mean $(\mathrm{kg}) \pm \mathrm{SE}$ \\
\hline$\overline{\text { Population mean }(\mu)}$ & 421 & $2438.98 \pm 38.49^{\mathrm{a}}$ \\
\hline \multicolumn{3}{|l|}{ Period of calving } \\
\hline $\mathrm{P}_{1}(1974-1980)$ & 126 & $3310.33 \pm 63.99^{\mathrm{a}}$ \\
\hline$P_{2}(1981-1987)$ & 65 & $2652.09 \pm 88.39^{b}$ \\
\hline $\mathrm{P}_{3}(1988-1994)$ & 66 & $2087.19 \pm 88.56^{\mathrm{c}}$ \\
\hline $\mathrm{P}_{4}(1995-2001)$ & 73 & $2065.57 \pm 84.03^{\mathrm{c}}$ \\
\hline $\mathrm{P}_{5}(2002-2008)$ & 60 & $2265.28 \pm 94.08^{c}$ \\
\hline$P_{6}(2009-2016)$ & 31 & $2253.38 \pm 129.04^{c}$ \\
\hline \multicolumn{3}{|l|}{ Season of calving } \\
\hline $\mathrm{S}_{1}$ (Rainy) & 109 & $2444.82 \pm 71.04$ \\
\hline $\mathrm{S}_{2}$ (Winter) & 153 & $2447.63 \pm 59.42$ \\
\hline $\mathrm{S}_{3}$ (Summer) & 160 & $2424.48 \pm 59.13$ \\
\hline
\end{tabular}

Means under each class in the same column with different superscript differed significantly

highest in cows calved during winter season $(14.36 \pm 0.22 \mathrm{~kg})$ followed by summer and rainy season. The results showed declined FLPMY in cows calved during later period. The higher monthly test day milk yield in HF X Gir cows calved in initial period $\left(\mathrm{P}_{1}\right)$ might be due to fact that during this period maximum number of cows were $\mathrm{F}_{1}$ halfbred having hetrotic effect. However, FLTDMY in later period declined as cows during later period were interbreeds of HFX Gir in those cows hetrotic effect might have been slightly declined.

The first lactation 300 days milk yield in HFX Gir halfbred was $2438.98 \pm 38.49 \mathrm{~kg}$. The difference due to period of calving in FL300DMY was significant $(\mathrm{P}<0.01)$. These results were in agreement with Bhadauria and Katpatal (2003) reported in Friesian $\mathrm{X}$ Sahiwal halfbred. Whereas, non-significant effect of period of calving on second lactation 300DMY was reported by Mote and Bhoite (2018) in FG halfbred. The mean FL300DMY of cows calved during $\mathrm{P}_{1}(3310.33 \pm 63.99 \mathrm{~kg})$ was significantly higher than cows calved in rest of the periods. The 300 days milk yield of cows calved during $\mathrm{P}_{2}(2652.09 \pm 88.39 \mathrm{~kg})$ was significantly higher than those calved in $\mathrm{P}_{3}$ to $\mathrm{P}_{6}$ periods which were at par with each other. The influence of SOC on 300 days milk yield in HF X Gir halfbred was non-significant. Non-significant effect of season of calving on 300 days milk yield was in accordance with Mote and Bhoite (2019) in Friesian X Gir half bred cattle. However the milk yield was highest in cows calved during winter season ( 2447.63 $\pm 59.42 \mathrm{~kg}$ ) and lowest in cows calved in summer season.

The heritability of monthly test day milk yield viz. $\mathrm{T}_{1}, \mathrm{~T}_{2}, \mathrm{~T}_{3}, \mathrm{~T}_{4}$, $\mathrm{T}_{5}$ and $\mathrm{T}_{6}$ in HF X Gir halfbred was $0.12 \pm 0.12,0.11 \pm 0.12,0.09 \pm 0.11$, $0.06 \pm 0.11,0.09 \pm 0.12$ and $0.09 \pm 0.13$ respectively. These results indicated that the heritability of monthly test day milk yield was low. Lower heritability estimates of MTDMY indicated higher role of environmental fluctuation on the trait. Similar low heritability of MTDMY was reported by Kumar et al. (2018) in crossbred cattle. The heritability of FLPMY and FL300DMY was $0.25 \pm 0.14$ and $0.12 \pm 1.00$ respectively.

The genetic correlations among various monthly test days milk yield were positive and significant $(\mathrm{P}<0.01)$ in $\mathrm{HF} \mathrm{X}$ Gir halfbred. Similar results were observed by Kumar et al. (2018) in crossbred cattle. The genotypic correlations between FL300DMY $(0.48 \pm 0.45)$ and peak milk yield as well as between monthly test day milk yield and 300DMY were positive and significant $(\mathrm{P}<0.01)$.

The Phenotypic correlations among the entire test day milk yield ranged from $0.51 \pm 0.03\left(\mathrm{~T}_{1}\right.$ with $\left.\mathrm{T}_{6}\right)$ to $0.84 \pm 0.01\left(\mathrm{~T}_{5}\right.$ with $\left.\mathrm{T}_{6}\right)$. Phenotypic correlation of peak milk yield with all monthly test day milk yield were positive and significant $(\mathrm{P}<0.01)$. The results indicated that in HFX Gir halfbred the genotypic and phenotypic correlations among FLMTDMY, FLPMY and FL300DMY were positive and significant.

Among the HF X Gir halfbred sires the highest EBV (16.82) based on FLPMY was noted for sire number H-281 and ranked first however the lowest EBV (13.27) was observed for sire number H242 and ranked last. On the basis of FL300DMY the sire number HG-272 had highest EBV (2810.17) and ranked first, whereas the lowest EBV (2319.45) was observed for sire number HG-45 and raked last.

\section{Conclusions}

In HF X Gir halfbred the effect of period of calving was significant while the season of calving was non-significant on MTDMY, FLPMY and FL300DMY. Heritability of all MTDMY and FL300DMY was observed to be low. However the medium $\mathrm{h}^{2}$ of FLPMY indicated that judicious selection of sires to improve the productivity of HF X Gir halfbred. The sire number H-325 had highest estimated breeding value for MTDMY while the sire number H-281 and HG-272 had highest estimated breeding value for FLPMY and FL300DMY, respectively.

\section{Acknowledgement}

The authors extend their sincere thanks to MPKV, Rahuri for providing the facilities for conducting the present investigation.

\section{References}

Bhadauria SS, Katpatal BG (2003) Effect of genetic and non- genetic factors on 300 days milk yield of first lactation in Friesian X Sahiwal crosses. Indian Vet J 80: 1251-1254

Gacula MC (Jr.), Gaunt SN, Demon RA. (Jr.) (1968) Genetic and environmental parameters of milk constituents for five breeds. Effect of herd, year, season and age of cow. J Dairy Sci 51: 428-437

Harvey R (1990) Least squares analysis of data with unequal subclass numbers. ARS H-4, U. S. D.A., Washington

Kramer CV (1957) Extension of multiple range tests to group correlated adjusted means. Biometrics 13: 13-20 
Kumar P, Dalal DS, Kumar S, Patil CS (2018) Genetics studies on test day milk yield records and first lactation milk yield in crossbred cattle. IJABR 8: 18-20

Meyer K (1998). Restricted maximum likelihood to estimate variance components for animal model with several random effects using a derivative free algorithm. Genet Select Evol 21: 317-340

Mote MG and Bhoite UY (2018) Factors affecting productive traits in Gir crosses. Indian J Anim Prod Mgmt 34: 40-44

Mote MG and Bhoite UY (2019) Genetic and Non Genetic Factors Affecting Milk Yield in Gir Crossbreds. Indian Vet J 96: 49-52
Mundhe UT, Gandhi RS, Das DN, Dongre VB and Singh AP (2018) Sire Evaluation Based on First Lactation 305 Day Milk Yield and Monthly Part Lactation Records in Sahiwal Cattle. Int J Livest Res 8: 228233

Rashia Banu N (2010) Genetic evaluation of lactation curve in Karan Fries cattle. Ph. D. Thesis submitted to NDRI, Karnal.

Snedecor GW and Cochran WG (2004) Statistical Methods. Affiliated East west press. Pvt. Ltd :466-490 